\title{
A UNIVERSAL APPROACH TO INTERNATIONAL LAW IN CONTEMPORARY CONSTITUTIONS: DOES IT EXIST?
}

\author{
Giulio Bartolini ${ }^{*}$
}

\begin{abstract}
The effectiveness of the international legal system and its capacity to be 'universal' is largely dependent on the attitude of domestic authorities towards international rules, which can be influenced by solutions provided in constitutions. Specific attention should be paid to the role and rank of sources of international law in domestic legal orders and their relationship with the constitution and other national sources. In the past, scholars identified three different approaches to this issue (Western constitutions, Socialist States and Third World countries). However, it is relevant to examine the current state of the art in contemporary constitutions, due to novelties concerning the attitude of States towards international sources. A survey of these texts reveals a spectrum of solutions, including: constitutions that ignore the topic; the express subordination of international law to the constitution and/or acts of Parliaments; and the predominance of general custom and/or international treaties over national legislation. This assessment clearly identifies some potential difficulties for international law to apply equally and indiscriminately across domestic legal systems even if a general survey indicates the increasing openness of contemporary constitutions towards international law. Consequently, a series of mechanisms have also been included in contemporary constitutions to solve conflicts between domestic and international rules. Nonetheless, in some instances, difficulties to reconcile international law with national constitutions can be recognised which contribute to undermining the 'universal' character of the international legal order.
\end{abstract}

\section{Keywords}

Constitution-making, Universality, Treaties, International Law, Domestic Law, Human Rights Treaties, Customary International Law

\section{Introduction: The Increased Relevance of International Law for Contemporary Constitution-Making Processes}

The international law dimension of a constitution is highly important, as the effectiveness of the international legal system and its capacity to be 'universal' is

Assistant Professor of International Law, University of Roma Tre.

Copyright $\odot$ the Author(s).

This work is licensed under a Creative Commons Attribution-NonCommercial-NoDerivs 3.0 License. 
largely dependent on the attitude of domestic authorities towards international rules. ${ }^{1}$ As Triepel asserted in 1923, international law is like a field marshal who can achieve his goals only if his generals (in this case, States) issue orders to their subordinates. ${ }^{2}$ Even if this metaphor was strongly influenced by Triepel's dualist perception of the relationship between the international and national legal orders, it still deserves attention as it emphasises the positive (or problematic) role that national rules can play in permitting the application of international law provisions within domestic legal systems.

In this regard, an analysis of specific provisions included in national constitutions concerning the role and rank of sources of international law in domestic legal orders, and their relationship with the constitution and other sources, is therefore essential. In fact, when a domestic constitution is 'friendly' to international law, ${ }^{3}$ the probability of the latter legal order being implemented increases, although an effective evaluation of a specific State's attitude towards international law is highly dependent on the concrete practice of its national organs. Therefore it is critical to examine the specific constitutional provisions of a State before making conclusions about that State's relationship with international law. Constitutions represent the main point of reference and source of legitimacy for the mandate of national legal actors potentially involved in addressing issues relevant for international law. ${ }^{4}$ Consequently, when constitutions misjudge the potential role of international law in domestic legal systems, international law finds it difficult to play its 'universal role'. Accordingly, avoiding potential conflicts between legal orders with contrasting exigencies becomes largely dependent upon creative interpretative solutions, which can be quite precarious.

From an international law perspective, even if this legal system provides neither guidance on how States should accommodate international law in their constitutions, nor indications concerning which mechanisms should be used to

${ }^{1}$ English translations of contemporary constitutions have been obtained through three main databases: World Constitutions Illustrated (HeinOnline); Oxford Constitutions of the World and 'Constitute' <www.constituteproject.org $>$.

2 H Triepel, 'Les rapports entre le droit interne et le droit international' (1923) 1 RCADI 106. For a similar position see A Cassese, 'Modern Constitutions and International Law' (1985) 3 RCADI 342.

${ }^{3}$ D Lovric, 'A Constitution Friendly to International Law: Germany and Its Völkerrechtsfreundlichkeit' (2006) 25 Aus YIL 75, 75.

${ }^{4}$ A Denza, 'The Relationship between International Law and National Law,' in M Evans (ed), International Law (2010) 411, 417: 'For each national legislature and court, the starting point for any examination of the relationship is its own constitution'. 
implement international sources at the domestic level, ${ }^{5}$ constitutions ought to not only be open to international law but also to be ready to accommodate international provisions in their legal systems. Arguably, the rationale for constitutions to pay tribute to international law does not principally derive from theoretical evaluations regarding the monist or dualist approaches of national legal systems with regard to international law. Indeed, several scholars have deemed these abstract approaches as incapable of concretely affecting the development or revision of domestic constitutions in this area, ${ }^{6}$ or of providing a clear picture of the practice in this regard. ${ }^{7}$ Instead, the rationale for international law's influence on domestic laws comes from one basic principle maintained by international law since its foundation - that is, the supremacy of international law over domestic laws and the impossibility for municipal legal systems to affect the application of international law.

International practice is constant in affirming this approach, mainly maintaining that a State cannot refer to its own legal order to justify its failure to comply with its international obligations. This basic principle has been persistently reiterated by arbitral and international tribunals, ready to recognise this solution notwithstanding the domestic relevance of the norms at issue. For instance, as early as 1875 the arbitral tribunal in the Montijo case maintained that 'a treaty is superior to the Constitution...The legislation of the Republic must adapt to the treaty, not the treaty to the law, ${ }^{8}$ according to a solution endorsed by the Permanent Court of International Justice. ${ }^{9}$ This principle has also been clearly ex-

5 See in general K J Partsch, 'International Law and Municipal Law', in R. Bernhardt (ed) Encyclopedia of Public International Law, vol 2 (1995) 238; P M Dupuy, 'International Law and Domestic (Municipal) Law,' (2011) Max Planck Encyclopedia of Public International Law (on-line edition).

6 Denza, above no. 4, 417.

7 J Crawford, 'Change, Order, Change. The Course of International Law' (2013) 365 RCADI 164, 164-5: 'Classifying a State's constitutional design as either monist or dualist is not so much an exercise in absolutes as a matter of degree...Neither theory provides a satisfactory explanation for the practice of international and national courts in articulating the content and design of legal systems'. See also E De Wet, 'The Constitutionalization of Public International Law,' in M Rosenfeld, A Sajó (eds), The Oxford Handbook of Comparative Constitutional Law (2012), 1209.

8 'Montijo' Arbitration (United States $v$ Colombia, 1875) per Mr Robert Bunch quoted in John Bassett Moore, History and Digest of the International Arbitrations to which the United States Has Been a Party, vol 2 (1898), 1440.

9 Treatment of Polish Nationals and Other Persons of Polish Origin or Speech in the Danzig Territory (1932) PCIJ Ser A/B no. 44, 32: 'a State cannot adduce as against another State its own Constitution with a view to evading obligations incumbent upon it under international law or treaties in force.' 
pressed in relevant treaties, such as article 27 of the Vienna Convention on the Law of Treaties. ${ }^{10}$ Codifications proposed by the International Law Commission (ILC) further reflect this principle, such as articles 3 and 32 of the Draft Articles on the Responsibility of States for Intentionally Wrongful Acts (Draft Articles on the Responsibility of States), ${ }^{11}$ which both reaffirm longstanding rules of customary international law in this area. ${ }^{12}$

This principle, which has been qualified by scholars as the result of 'une supériorité logique ${ }^{13}$ of international law over municipal laws, is clearly linked to its intrinsic necessity for the international legal order. Indeed, Gaja has argued that, without it, 'the binding character of international law would be put in jeopardy.' ${ }^{14}$ As maintained by Virally, for instance, 'Le droit international est inconcevable autrement que supérieur aux Etats, ses sujets. Nier sa supériorité revient à nier son existence. ${ }^{15}$ Moreover, this supremacy could also provide international law with the fundamental benefit of receiving the support of domestic actors and mechanisms in achieving its application. In this way, it is argued that international law may guarantee the realisation of the ideal model ... [in which] both the national legal order and the international legal order would be in charge of the application of the international norm. ${ }^{16}$ The effectiveness of international law could therefore be increased by a proper accommodation of international law principles and sources in domestic constitutions.

Consequently we could expect States involved in constitution-making processes to be ready to properly evaluate the relationship between international law and domestic sources, especially taking into account the current dynamics of the international legal order. While basic references to international law have been included in the evaluations of constitution-makers since the earliest constitutional instruments, it would seem that the relationship and interaction between

\footnotetext{
1023 May 1969, 1155 UNTS 331.

11 Report of the ILC on the Work of its Fifty-third Session, UN GAOR, $56^{\text {th }}$ Sess., Supp. No. 10, p. 43, UN Doc A/56/10 (2001).

12 M Villiger, Commentary on the 1969 Vienna Convention on the Law of Treaties (2009), 374-5.

13 D Carreau, Droit international (9th ed, 2007), 59.

${ }^{14}$ G Gaja, 'Dualism - A Review', in J Nijman, A Nollkaemper (eds), New Perspectives on the Divide between National and International Law (2007), 61.

${ }^{15}$ M Virally, 'Sur un pont aux âjes: les rapports entre droit international et droits internes,' in H Rolin, Mélanges offerts à Henri Rolin: problèmes de droit des gens (1964) 488, 497. See, in similar terms, G Fitzmaurice, 'The General Principles of International Law Considered from the Standpoint of the Rule of Law' (1957) 92 RCADI 1.

${ }^{16}$ P Dupuy, 'The Unity of Application of International Law at the Global Level and the Responsibility of Judges' (2007) 1(2) EJLS 2.
} 
the international and national legal orders is probably at its zenith today. Indeed, Franck and Thiruvengadam's view that ' $\mathrm{n}] \mathrm{o}$ constitution, today, is an island unto itself, ${ }^{, 17}$ would seem to be irrefutable.

In this context, a series of partly interrelated factors have facilitated the further interaction between international and national legal orders. These factors include: (1) the development of universal and regional integration within the framework of international organisations endowed with law-making or other relevant powers, which are able to influence not only the conduct of State organs but also the activities of private and legal persons; (2) the ever-growing interdependence of States and the increasing relevance of international obligations in several areas pertaining to the public activities of States, with an obvious reduction of their domaine reservé; (3) the development of international human rights standards capable of complementing provisions at the national level, thus creating fruitful interaction in this area in terms of both the substantive provisions and the control mechanisms available at multiple levels of protection; and (4) parliaments' increased exigencies in terms of democratic control over the executive's external activities in areas pertaining to international law.

Moreover it should be emphasised that external actors have actively contributed to constitution-making processes in several recent cases, thus embracing an area traditionally qualified as the hallmark of States' sovereignty and selfdetermination. The degree of internationalised pouvoir constituant has, however, varied widely. ${ }^{18}$ On one end of the spectrum it includes constitutions internationally octroyées, such as that of Bosnia-Herzegovina, where the content of the supreme law of the land was included in an international instrument, i.e. Annex IV to the Dayton Agreement. ${ }^{19}$ The other extreme involves advisory functions and supervision exercised in a more or less stringent manner by international organisations, such as the United Nations (UN) or the Council of Europe's Venice Commission, or by relevant third States. Various experiences may be relevant in this regard, such as those of Namibia, South Africa, East Timor, Afghanistan, Iraq,

17 T M Franck and A K Thiruvengadam, 'International Law and Constitution-Making' (2003) 2 Chinese JIL 467, 468.

18 See N Maziau, 'L'internationalisation du pouvoir constituant. Essai de typologie: le point de vue heterodoxe du constitutionnaliste' (2002) 106 RGDIP 549; P Dann \& Z Al-Ali, 'The Internationalized pouvoir constituant - Constitution-Making Under External Influence in Iraq, Sudan and East Timor' (2006) 10 Max Planck Yearbook of United Nations Law, 423; V Sripati, 'The United Nation's Role in Post-Conflict Constitution-Making Process; TWAIL Insight' (2008) 10 Int Comm L Rev 411; E Hay, 'International(ized) Constitutions and Peacebuilding' (2014) 27 Leiden IIL 141.

${ }^{19}$ S Yee, 'The New Constitution of Bosnia and Herzegovina,' (1996) 7 EJIL 176. 
Kosovo, South Sudan, Angola and Kenya, to name but a few.

Reference to these recent constitution-making processes tends to introduce a key limitation to the focus of my research. In particular, this article will primarily address written constitutions (or relevant modifications to existing texts) adopted since the 1990s. This temporal delimitation is far from arbitrary. As emphasised by Cassese, ${ }^{20}$ prior to the last decade of the twentieth century, three main attitudes of domestic constitutions towards international law were identifiable. These were mainly influenced by political and historical factors, which had a fundamental influence on States' legal approaches towards international law. In particular, a comparative review of existing constitutional provisions in that period reveals three main alignments (Western, Socialist and Third World States) with specific features in relation to these issues. While all States, whatever their ideology and legal tradition, were cautious in proclaiming their formal adherence to international law, distinct groups of States can be assigned to a spectrum of different attitudes vis-à-vis international law.

Broadly speaking, several Western countries tended to recognise a significant role for sources of international law (both customs and treaties), in some cases formally admitting their superiority with regard to municipal laws, with the exception of safeguard caveats aiming to maintain the constitution as the supreme law of the land. On the contrary, the constitutions of Socialist countries and Third World States, especially 'newcomers' to the international arena such as States involved in the decolonisation process, did not even pay lip service to international law.

For instance, the absence of any formal reference to the role of international customs in the latter's domestic legal orders was very common. This omission was motivated by different factors, such as: (1) the long-standing sceptical attitude of Socialist States towards general international law, whose value was only admitted as the result of Socialist States' express or tacit endorsement; (2) 'colonial' influences in constitution-making processes, such as the absence of formal reference to international customs in the 1958 French Constitution or, similarly, the idea in former British colonies that an unwritten rule - to the effect that customary law was part of the law of the land - could be sufficient; and (3) the international law agenda of several Third World States, accompanied by fierce criticisms of the existing legal order and the role of existing customs, which were largely qualified as the product of and an infliction from developed States. ${ }^{21}$ In

\footnotetext{
${ }^{20}$ A Cassese, 'Modern Constitutions,' above n 2, 331.

${ }^{21}$ See T Maluwa, International Law in Post-Colonial Africa (1999), 42; F Okoye, International Law and
} 
a similar way, several constitutions of Socialist and Third World States neither mentioned nor attributed a specific role and rank to treaties in their domestic legal systems.

This potential three-group qualification of States' approaches to constitutions with regard to international law could not have survived the historical and legal events that followed 1989. These events resulted in the development of an impressive number of constitution-making processes in the last two decades, which clearly emphasised the need to reassess national constitutions' attitudes towards international law.

A first point of departure was the abandonment of Socialist approaches to international law in domestic constitutions. The Socialist legal legacy no longer represented a suitable normative approach for national constitutions and consequently all former Communist States, especially in Europe and Central Asia, were involved in drafting new constitutions. As analysed later on, these States showed a clear tendency to pay formal tribute to international law. ${ }^{22}$ In this way, they recalled the 'fièvre internationaliste de l'immédiat après-guerre ${ }^{23}$ of several Western States that had experienced authoritarian regimes and were more open to pledging fidelity to international legal values. Several other States, particularly Latin American and African ones, were also abandoning authoritarian regimes at the time, a phenomenon that had a significant impact on their constitutions.

From the early 1990s, the majority of African constitutions were abrogated to be replaced by new texts aimed at promoting (at least from a formal point of view) the rule of law, democracy and division of powers. ${ }^{24}$ This opportunity also led to a reconsideration of the role of international law in such domestic systems to varying extents, partly influenced by the less competitive and challenging positions of these States with regard to the international legal system. ${ }^{25}$ By way

the New African States (1972), 193-4.

${ }^{22}$ As maintained by Vereshchetin 'one of the common features of all new constitutions in that region is their openness to international law' (V S Vereshchetin, 'New Constitutions and the Old Problem of the Relationship between International Law and National Law' (1996) 7(1) EJIL 29, 32). For a similar position see E Stein, 'International Law in Internal Law: Toward Internationalization of Central-Eastern European Constitutions?' (1994) 88 AJIL 427; S Marochkin, 'Place and Role of Norms and Sources of International Law in the Legal System of the Russian Federation: The Doctrinal Exploration and the Legislative Development of the Constitutional Principles' (2012) 3 BLR 31.

${ }^{23}$ De Visscher, 'Les tendances internationales des constitutions modernes' (1952) RCADI 573. See also in this regard Cassese, 'Modern Constitutions,' above n 2, 351.

${ }^{24}$ On this phenomenon see for instance: H. Roussillon (ed.), Les nouvelles constitutions africaines (2nd ed, 1995); P F Gonidec, 'Constitutionnalismes africaines', (1996) African J Int L 12.

${ }^{25}$ We can mention, for instance, African States' re-emerging interest in the arbitral function of the 
of example, Namibia was the first post-colonial African country to expressly recognise the role of international customs as a source of domestic law in its 1990 Constitution, an approach subsequently adopted by other African States. ${ }^{26}$ In this regard it could be argued that Namibia's willingness to accept the role of international law in its constitution may have been due to its emergence as an independent State through the active involvement of the international community and receipt of international support in its constitution-making process. Similarly, in some constitution-making processes, such as the drafting of the South African Constitution, issues related to international law were subjected to specific scrutiny, resulting in the adoption of provisions that emphasised the openness of the domestic legal system to international values. ${ }^{27}$ This innovative solution clearly had an impact on other African States.

In a similar way, Latin American States were also involved in transitional political processes which had an important impact on their domestic constitutions. Some of these States had common approaches to international law, especially in their original 'constitutionalisation' of international standards pertaining to human rights law by granting constitutional status to treaties and soft-law documents developed at both universal and regional levels. ${ }^{28}$

During this period other States, while less affected by substantial constitution-making processes, still had to deal with the increasing intrusion of international law into municipal legal systems, as highlighted, for example, by the constitutional provisions adopted in Europe to address regional integration. Finally, political events continue to imply significant modifications to constitutions as a potential outcome, as recently emphasised by the 'Arab Spring,' which has led to the abrogation of several constitutions in the area, thus ensuring that the role of international law in domestic legal systems is a constant subject of potential debate. $^{29}$

International Court of Justice after the crisis prompted by the decision of the ICJ in the Southwest Africa Case (Liberia v South Africa) ICJ Reports 1966.

${ }^{26}$ On the relevance of section 144 of the 1990 Namibian Constitution see T Maluwa, International Law, above no. 21, 48; Frank and Thiruvengadam, 'International Law', above n 17, 508.

${ }^{27}$ See J Dugard, 'International Law and the South African Constitution' (1997) 1 EJIL 77; D J Devine, 'The Relationship between International Law and Municipal Law in the Light of the Interim South African Constitution 1993' (1995) 44 ICLQ 1.

${ }^{28}$ T Buerghenthal, 'Modern Constitutions and Human Rights Treaties' (1998) 36 Colum. J Trans L 211.

${ }^{29}$ Mention could be made of the Venice Commission's critical remarks on the draft Tunisian Constitution, with regard to its provisions dealing with international law. See: European Commission for Democracy through Law, Opinion on the Final Draft Constitution of the Republic 
In light of this survey of interrelated factors, an examination of constitutional provisions adopted in this area since the 1990s allows us to assess whether it is finally possible to identify clear and common patterns regarding the relationship between international and domestic sources of law as provided by national constitutions. In particular, as it will be impossible to focus on all relevant aspects of the so-called 'internationalisation' of contemporary constitutions, ${ }^{30}$ our attention will instead be focused on an analysis of the formal rank attributed to international sources of law in relation to municipal ones, as this is one of the main indicators of the potentially fruitful or problematic nature of the relationship between these sources.

However, an empirical analysis of these primary sources reveals the difficulties of identifying unique solutions, as States continue to maintain an 'anarchic' approach in this area. ${ }^{31}$ This first partial conclusion must, however, be qualified. In particular, taking into account the state of the art with regard to constitutional provisions in this area prior to the 1990s, it seems clear that contemporary constitution-making processes tend to follow similar key trends with regard to some aspects. In our opinion an overall assessment allows us to conclude that the current tendency is to attribute a significant formal role to sources of international law in domestic constitutions, subject to certain caveats and in particular to the problematic relationship with the constitution itself. However, while these potential limits may still appear unsatisfactory from an international law perspective, it seems certain that contemporary constitution-making processes are increasingly open to international law and conscious of the far-reaching relevance of international obligations and standards for national authorities, thus potentially permitting international law to play its 'universal and cosmopolitan' role.

\footnotetext{
of Tunisia (2013), para 38-40.

${ }^{30}$ From a constitutional law perspective on these issues, see W Chang and J Yeh, 'Internationalization of Constitutional Law,' in M Rosenfeld \& A Sajo (eds), The Oxford Handbook of Comparative Constitutional Law (2013) 1165; A Levade \& B Mathieu, 'L'internationalisation du droit constitutionnel. Acteurs - domaines - techniques' (2006) 18 ERPL 161.

${ }^{31}$ A Cassese, International Law ( ${ }^{\text {nd }}$ edition, 2004), 220.
} 


\section{Treaties and Their Rank in Contemporary Constitutions}

In considering contemporary constitutions' approaches to international sources, the legal standing of treaties within domestic legal orders can be identified as a first point of reference. As international law is increasingly intrusive in domestic affairs due to the networks of treaties binding States, it is evident that such international sources can have a significant impact on domestic legal orders and raise potential conflicts with national sources. In this regard, provisions included in contemporary constitutions help to identify some of the main issues, such as the relationship between treaties, the constitutions themselves, and acts of Parliament, which is sometimes influenced by the subject of the international treaty as in the case of human rights conventions. Furthermore constitutions also include provisions that aim to clarify the possibility and requirements for international treaties to produce legal effects on the domestic legal order, thus providing some indications of implementation techniques adopted by the relevant State.

\subsection{The Relationship between Constitutions and International Treaties}

As emphasised above concerning the relationship between constitutions and treaties, international adjudication bodies have constantly reaffirmed the impossibility for States to invoke their constitutional provisions as a defence for the non-fulfilment of international obligations. However, this position has encountered clear difficulties in acceptance at the domestic level as " $\mathrm{t}$ ]raditionally, a constitution is perceived as essentially a state-centered notion which is linked to the concept of statehood and the idea of a state exercising its sovereign power. ${ }^{32}$ Consequently, early examples of constitutions and relevant case-law took the opposite position, considering the supreme law of the land to have priority over treaties, ${ }^{33}$ while only the Dutch Constitution recognised a different potential position. $^{34}$

\footnotetext{
${ }^{32} \mathrm{C}$ M Fombad, 'Internationalization of Constitutional Law and Constitutionalism in Africa' (2012) 60(2) Am J Comp L 439, 441.

${ }^{33}$ See Cassese, 'Modern Constitutions,' above n 2, 368-93.

${ }^{34}$ Among the early examples of constitutions, only that of the Netherlands is considered to provide treaties with supremacy over the constitution. In the case of the Netherlands constitution, a treaty that conflicts with the constitution has to be approved by Parliament with at least a
} 
A similar trend can be identified with regard to contemporary constitutions. Consequently, authors such as Peters have affirmed that 'not unsurprisingly, the issue seems to be tackled almost exclusively in young, mostly post-transition State constitutions, which have been created in an area already marked by globalisation. ${ }^{35}$ Even if Peters' evaluation was based on a Euro-centric analysis, comprehensive examination allows us to confirm that numerous contemporary constitutions proclaim the impossibility for international law sources to contradict the constitution. At a glance these provisions could still be interpreted as indicating a 'nationalistic' constitutional approach that is sceptical of international law, as they tend to confirm that international values and obligations cannot be introduced into the domestic legal order when in contrast with the constitution.

Nonetheless, from our perspective these clauses take a less competitive approach vis-à-vis international law than would appear prima facie and than may be expected. In fact in the majority of cases the supremacy of constitutions over international law is inferred or complemented by provisions defining the role of constitutional or superior courts, which are required to evaluate the compatibility of treaties with constitutional values, usually prior to their ratification, ${ }^{36}$ as for instance maintained by article 72 of the 1995 Constitution of Kazakhstan, according to which 'the Constitutional Council shall...consider the international treaties of the Republic with respect to their compliance with the constitution, before they are ratified.' This approach is familiar to numerous contemporary constitutions, such as those of: Afghanistan (2004, article 121); Albania (1998, article 131); Andorra (1993, article 46.1); Angola (article 6, 228); Armenia (1995, article 6, 100); Azerbaijan (1995, article 130); Benin (1990, article 146); Bolivia (2009, article 256); Brazil (1988, article 102); Bulgaria (article 85.4, 149.1); Burkina Faso (1991, article 150); Burundi (2005, article 296); Cape Verde (2010, article 12.4, 278); Central African Republic (2004, article 71); Chad (1996, article 220); Colombia (1991, article 241); Comoros (2001, article 10); Congo (2001, article 146, 183); Côte d’Ivoire (2000, article 86); Croatia (1991, article 140); Czech Republic

two-thirds majority of the vote: a majority substantially similar to that required to formally revise the constitution itself. See E A Alkema, 'Netherlands,' in D. Shelton (ed.), International and Domestic Legal Systems: Incorporation, Transformation, and Persuasion (2011), 421-2.

${ }^{35}$ A Peters, 'The Globalization of State Constitutions,' in J Nijman \& A Nollkaemper (eds), New Perspectives, above n 14, 260.

${ }^{36}$ In some rare cases the vague terms of relevant constitutional provisions also seem to imply the possibility of ex-post constitutionally test, a solution that can obviously create legal problems if the instrument is already legally binding for the State and a previous examination of the constitutional legitimacy of the treaty has not been carried out according to the possibility grant by the constitution. 
(1993, article 87); Democratic Republic of Congo (2005, article 216); Dominican Republic (2010, article 185); Ecuador (2008, article 425); Equatorial Guinea (1991, article 94); Gabon (1001, article 87); Georgia (1995, article 6, 89); Guinea (2010, article 93); Kazakhstan (1995, article 72); Kyrgyzstan (2010, article 97.6); Lithuania (1992, article 105); Madagascar (2010, article 116, 137); Mali (1992, article 90); Mauritania (1991, article 79); Mongolia (1992, article 10.4, 66); Morocco (2011, article 55); Niger (2010, article 120, 170); Poland (1997, article 133, 188); Romania (1991, article 11, 146); Russia (1993, article 125); Rwanda (2003, article 145, 192); Senegal (2001, article 97); Slovakia (1992, article 125); Slovenia (1991, article 160); Togo (1992, article 138); Tunisia (2014, article 20, 120); Ukraine (1996, article 9, 151); Uzbekistan (1992, article 109); and Venezuela (1999, article 336). In other cases the constitutions simply make it impossible to ratify and/or apply treaties contrary to the constitution without providing for the involvement of superior courts in this area, as in the case of: Belarus (1994, article 8); Bhutan (2008, article 25); and Estonia (1992, article 123). Only in some rare cases the constitutional provisions maintain the priority of the constitution over ratified treaties or imply the possibility of an ex-post constitutionally test after the ratification process, according to solutions that can obviously create legal problems of State responsibility. ${ }^{37}$ Similarly in a few constitutions, such as article 10 of the 1994 Tajikistan constitution, the constitution's supremacy is simply upheld in relevant provisions that generally define the rank of domestic and international sources, thus implying the inferiority of the latter with regard to the supreme law of the land.

Consequently, rather than merely proclaiming the supremacy of their provisions, the majority of these constitutions tend to define a prearranged mechanism to both favour legal certainty and avoid potential conflicts between international law and the constitution. In doing so, they attribute to national superior courts the ability to review the constitutionality of treaties during the treatymaking process. Constitution-makers are thus perfectly aware of the potential difficulties raised by such constitutional safeguard provisions with regard to international law. Accordingly, they aim to prevent conflicts between domestic and international law by relying on certain mechanisms aimed at avoiding potential frictions between international and domestic legal orders. It is therefore the duty of national authorities to evaluate whether to afford precedence to international interests, thus modifying the constitution, or to maintain the supremacy of the

\footnotetext{
${ }^{37}$ See e.g. Serbian Constitution (2006), Arts 16, 167 and 194. See also S Djanjić, 'Serbia', in D Shelton, above 34, 544-6.
} 
constitution but avoid creating situations of international responsibility for the State simply by not ratifying the proposed treaty.

Therefore, several constitutions also provide that ' $t$ ] he conclusion of international treaties, which require any amendments to the Constitution, shall be preceded by the passage of the said amendment. ${ }^{38}$ This solution clearly echoes article 54 of the 1958 French Constitution, the principle underlying which is now common to several domestic systems unrelated to the French constitutional experience $^{39}$. While this process can obviously be time-consuming for the State participating in the relevant treaty, it permits the achievement of an appropriate balance between international and domestic interests, avoiding subsequent situations of potential conflict that could risk raising issues of State responsibility. As it is known, in several cases States have opted to modify their constitutions before ratifying an international treaty whose provisions had the potential to conflict with constitutional rules or, similarly, they have introduced references to these treaties in their constitutions in order to grant them a constitutional guarantee and facilitate their application at the domestic level. This was recently emphasised by the saga of the ratification process of the Statute of the International Criminal Court, which required several States to introduce constitutional modifications. $^{40}$

Conversely, in some rare cases, the Constitutional Court is required to review the 'compatibility of a proposed constitutional amendment with binding international agreements ratified under this Constitution., ${ }^{41}$ In this latter case the role of international law as a fundamental parameter of reference in the law-making process of domestic legislative authorities has been reaffirmed. Constitutionmakers have adopted a cooperative approach towards international law in order to evaluate in a preventive manner whether the proposed constitutional changes could imply the international responsibility of the State in cases of future nonfulfilment of treaty obligations that are no longer in line with the constitution.

Domestic mechanisms aimed at avoiding situations of incompatibility between the constitution and international obligations can also be reinforced by

\footnotetext{
${ }^{38}$ Bulgarian Constitution, Art 85.4.

${ }^{39}$ See e.g. Madagascar (2010, Art 137); Mali (1992, Art 90); Morocco (2011, Art 55); Niger (2010, Arts 120 and 170); Peru (1993, Art 57); Romania (1991, Art 11); Rwanda (2003, Art 192); Senegal (2001, Art 97); and Ukraine (1996, Art 9).

${ }^{40}$ See H Duffy, 'National Constitutional Compatibility and the International Criminal Court' (2001) 11 Duke JCIL 5. See e.g. references to the Statute of the International Criminal Court in the Constitutions of: Colombia (Art 93); France (Art 53.2); Ireland (Art 29); Kenya (Art 134).

${ }^{41}$ Kosovo Constitution (2008), Art 113.3.
} 
international mechanisms, as in the case of reservations to multilateral treaties. Such reservations can represent an additional opportunity to achieve an equilibrium between competing interests, with the aim of impeding the violation of a State's core constitutional principles. As it is known, in several cases States have included reservations, claiming that the entry into force of the international instrument cannot restrict constitutional provisions or should be interpreted according to its terms, thus maintaining the supremacy of constitutional values in relevant areas. ${ }^{42}$ In some States this possibility is also envisaged by the constitution itself: article 145 of the El Salvador Constitution provides for the ratification of treaties contrary to the constitution as long as State organs include pertinent reservations at the time of ratification. ${ }^{43}$

It follows that systems adopted in several constitutions are intended to seek an appropriate balance between the international and domestic legal orders, rather than picture this relationship in terms of insoluble tensions. Furthermore, these constitutional clauses present an additional advantage as they expand democratic control over a State's external activities. In fact, they usually permit several State organs (members of Parliament or supreme representatives of Parliament, government, Presidents of the Republic, judicial authorities, etc.) to demand an evaluation of the constitutional compatibility of the proposed treaty. In this manner the sphere of stakeholders is enlarged, who can perform checks and balances in this area in order to prevent predominant domestic actors in foreign affairs (such as the executive or the President of the Republic) from potentially undermining basic domestic values through their external activities, or from concluding international treaties that infringe on the competency of other constitutional bodies, such as Parliament. ${ }^{44}$

\subsection{Treaties and Acts of Parliament}

The rank of treaties with regard to acts of Parliament is an additional element that sheds light on the attitude of contemporary constitutions and their treatment of

\footnotetext{
${ }^{42}$ See e.g. the dozens of reservations introduced by States to the 1966 Covenant on civil and political rights in order to maintain their compatibility with their national constitutions. See for example the Gambia's reservation regarding art. 14 CCPR 'For financial reasons free legal assistance for accused persons is limited in our constitution to persons charged with capital offences only. The Government of the Gambia therefore wishes to enter a reservation in respect of article 14 (3) (d) of the Covenant in question'.

${ }^{43}$ See for instance article 145 of the El Salvador Constitution.

${ }^{44} \mathrm{~T}$ Ondo, 'Le contrôle de constitutionnalité des engagements internationaux par la Cour constitutionnelle du Gabon’ (2013) 90 RDIC 213, 218.
} 
international sources. The latter can have a significant impact on domestic legal orders and raise potential conflicts with subsequent domestic sources. This is the case particularly in the situation discussed above - where international law increasingly intrudes into domestic affairs due to networks of treaties binding States.

In this area a significant shift is appreciable between texts adopted prior to the 1990s and subsequently. In the first period constitutions that formally granted treaties a higher position than acts of Parliament were rare. In some cases, indeed, constitutional reforms actually 'downgraded' the rank of treaties, even when previously vested with a superior authority. ${ }^{45}$ On the contrary a current trend in contemporary constitutions is to favour the recognition of a special status to international treaties within the domestic legal order, thus increasing the formal openness of contemporary constitutions with respect to international law. In particular, various texts contain provisions similar to article 122.2 of the 1998 Albanian Constitution, according to which '[a]n international agreement ratified by law has priority over the laws of the country that are incompatible with it'. Similar provisions (or identical solutions inferred from the rank attributed to different legal sources ${ }^{46}$ ) can be identified in the constitutions of: Andorra (1993, article 3); Argentina (1994, article 75); Armenia (1995, article 6); Azerbaijan (1995, article 151); Benin (1990, article 147); Bolivia (2009, article 410); Bulgaria (1991, article 5); Burkina Faso (1991, article 151); Cape Verde (2010, article 12.4); Central African Republic (2004, article 72); Chad (1996, article221); Comoros (2001, article 10); Congo (2001, article 184); Côte d'Ivoire (2000, article 87); Croatia (1991, article 140); Czech Republic (1993, article 10); Democratic Republic of Congo (2005, article 215); Djibouti (1992, title VI); East Timor (2002, article 9.3); Ecuador (2008, article 425); Estonia (1992, article 123); Georgia (1995, article 6); Guinea (2010, article 151); Italy (amendment 2001, article 117); Kazakhstan (1995, article 4); Kosovo (2008, article 19); Macedonia (1991, article 118); Madagascar (2010, article 137); Mali (1992, article 116); Mauritania (1991, article 80); Montenegro (2007, article 9); Mozambique (2004, article 18); Niger (2010, article 171); Paraguay (1992, article 137); Poland (1997, article 91); Russia (1993, article 15); Rwanda (2003, article 190); Senegal (2001, article 98); Slovenia (1991, article 8, 153); Tajikistan (1994, article 10); Togo (1992, article 140); Turkmenistan (2008, article 6); and Tunisia

${ }^{45}$ Cassese, 'Modern Constitutions,' above n 2, 405, citing the examples of constitutional reforms involving Benin, Congo, Madagascar, Suriname, Turkey, Syria.

${ }^{46}$ See e.g. Bolivian Constitution, Art 410: ‘...The application of the legal norms shall be governed by the following hierarchy...: 1. Constitution of the State; 2 . International Treaties; 3 . National Laws.... 
(2014, article 20).

The clear aim of these constitutional provisions is mainly to avoid the infringement of international obligations by the State in question. Constitutionmakers have sought to avoid such infringements by formalising a preference for international treaties in the text of the constitution itself. It follows from such a constitution-making trend that the need to increase the role of Parliaments in the treaty-making process is even greater and can be justified not only by the maintenance of democratic control over foreign policy, but also by the need to ensure supervision over States when entering into treaties. As emphasised above, these international sources can definitively impact Parliament's capacity to act as lawmaker at the domestic level. Thus constitutions commonly include provisions defining the extent of parliamentary involvement in the treaty-making process. ${ }^{47}$

Nonetheless, the current relevance of constitutional provisions proclaiming the formal superiority of international treaties could certainly be increased by the inclusion of a series of additional positive tools. For instance, some constitutions require superior courts to review the compatibility of subsequent acts of Parliament with respect to ratified international treaties. In this sense, article 149 of the 1991 Bulgarian Constitution provides the Constitutional Court with the power to rule 'on the compatibility of domestic laws with the universally recognized norms of international law and the international treaties to which Bulgaria is a party'. Similar provisions can be found in other constitutions. ${ }^{48}$ Furthermore, while few constitutions explicitly refer to superior courts' ability to undertake the judicial review of legislation to establish whether it infringes international norms, it should be emphasised that the abovementioned constitutional provisions (claiming that duly ratified treaties can override national legislation) could also benefit from mechanisms of 'common' constitutional review to enforce their superiority. In these cases, the authority vested in such tribunals and their capacity to guarantee a uniform solution at the domestic level clearly help to reaffirm the priority of international treaties and ensure that provisions proclaiming their superiority have more than a merely declaratory nature.

\footnotetext{
${ }^{47}$ Some constitutions even require that all treaties be submitted to Parliament for ratification. See e.g. Bhutan Constitution (2008), Art 10 ('...all international conventions, covenants, treaties, protocols and agreements duly accepted by the Government hereafter, shall be deemed to be the law of the Kingdom only upon ratification by Parliament'); Colombian Constitution (1991), Art 224 ('In order to be valid, treaties must be approved by Congress'). For extensive lists of categories of treaties to be approved by the Parliament before being ratified by the State see e.g.: Bulgaria (1991, Art 85); Central African Republic (2004, Art 69); and Thailand (2007, Art 190).

${ }^{48}$ See e.g.: Ecuador (2008, Art 425); and Montenegro (2007, Art 149).
} 
As mentioned, the formal recognition by constitutional provisions of the superiority granted to international treaties can certainly favour the implementation of such treaties. Nonetheless it should be pointed out that, even in its absence, domestic legal orders have already managed to develop a series of legal techniques aimed at attributing precedence to international treaties in relation to subsequent acts of Parliament that conflict with treaty provisions. Indeed, various solutions have aimed at favouring judicial interpretations of subsequent statutes in line with the provisions of treaties, thus avoiding - as far as possible - solutions implying the international responsibility of the States involved. In particular we could refer to the doctrine of consistent interpretation which is used in order to apply domestic law in harmony with international provisions. ${ }^{49}$ In some cases, contemporary constitutions have included provisions formally requiring domestic actors to adopt this interpretative approach to prevent conflicts between international and municipal law as maintained by article 91 of the 1997 Poland Constitution according to which 'An international agreement...shall have precedence over statutes if such an agreement cannot be reconciled with the provisions of such statutes'. Such provisions thus crystallise a solution that clearly favours the openness of the domestic legal system towards international law. This openness is made particularly explicit in the South African constitution, section 233 of which provides that " $[\mathrm{w}]$ hen interpreting any legislation, every court must prefer any reasonable interpretation of the legislation that is consistent with international law over any alternative interpretation that is inconsistent with international law'. Through these provisions the possibility to refer to the doctrine of consistent interpretation is clearly maintained in the municipal legal system thus facilitating the possibility for domestic judges to pay judicial deference with respect to international law.

\subsection{Human Rights Treaties and Contemporary Constitutions}

Our discussion of the rank of treaties with regard to domestic legislation would not be complete without a separate section devoted to a specific category ratione materiae of international treaties: human rights conventions. A survey of contemporary constitutions clearly emphasises that, in several cases, human

\footnotetext{
${ }^{49}$ See e.g. G Betlem \& A Nollkaemper, 'Giving Effect to Public International Law and European Community Law before Domestic Courts. A Comparative Analysis of the Practice of Consistent Interpretation' (2003) 3 EJIL 569. For the approach used by States adopting common law traditions, see M Kirby, 'International Law: The Impact of National Constitutions' (2006) 21 Am ULR 327; S Fatima, Using International Law in Domestic Courts (2005) 296-315.
} 
rights treaties have acquired an even more important status than 'ordinary' treaties. Various solutions have been adopted in this regard, all tending to emphasise the relevance attributed by constitution-makers to similar treaties that are qualified as a fundamental part of the domestic legal system. This trend has also been facilitated by the functional need to pay formal attention to human rights standards. In the framework of key supranational regional organisations, such as the Council of Europe or the EU, these standards represent a fundamental prerequisite for admission. Consequently States involved in constitution-making processes which intend to join these international organisations have a strong incentive to accommodate international human rights law into their domestic legal orders in a proper manner.

A first hypothesis is the so-called 'constitutionalisation' of international human rights treaties, by attributing a constitutional rank to a series of international human rights instruments. For instance article 19 of the 2004 Constitution of Burundi maintains that 'The rights and duties proclaimed and guaranteed, among others, by the Universal Declaration of Human Rights of December 10, 1948, the International Human Rights Pacts of December 16, 1966, the African Charter on Human and Peoples' Rights, the Convention on the Elimination of all Forms of Discrimination against Women and the Convention on the Rights of the Child are an integral part of the Constitution of the Republic of Burundi.' Similarly this is the case, for example, with the constitutions of: Argentina (1994, article 75); Benin (1990, article 7); Bosnia-Herzegovina (1995, article 2 and annexes); Brazil (amendment 2004, article 5.3); Congo (2001, preamble); Dominican Republic (2010, article 74); Djibouti (1992, preamble); Mexico (2011, article 1); Togo (1992, article 50); and Venezuela (1999, article 23). In this regard the constitutions usually list a series of pertinent universal and regional treaties, while in some cases reference is also made to documents originally adopted as non-binding instruments, such as the Universal and American Declarations of Human Rights, ${ }^{50}$ reflecting the increasingly frequent assumption that these texts have a normative character. Through the attribution of a constitutional rank to such international human rights instruments, they tend to acquire a special status in the domestic legal order, thus implying that their content cannot be repealed by acts of Parliament. Similarly, without expressly attributing a constitutional status to human rights treaties, other constitutions formally guarantee such conventions a higher rank than acts of Parliament, as affirmed, for instance, by article 93 of the Colombian Constitution according to which 'International treaties and agreements ratified by Congress that

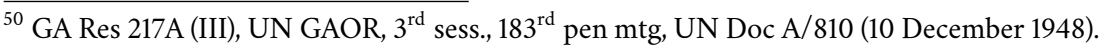


recognize human rights and that prohibit their limitation in states of emergency have priority domestically.' A similar solution is maintained by several constitutions as the constitutions of: Bolivia (2009, article 13); Ecuador (2008, article 424); Kosovo (2008, article 22); Kyrgyzstan (2010, article 6); Romania (1991, article 20); and Slovakia (1992, article 7, 154).

In these cases, the relevance of such solutions can vary according to the constitution's general attitude with regard to treaties. In the case of constitutions that already formally recognise a higher status to 'common' international treaties, the added value of special provisions concerning human rights conventions may be quite modest, as in the case of the Constitution of Benin. On the contrary, in the case of constitutions that only attribute a special rank in the domestic legal system to human rights treaties, such as the Argentinian Constitution, the impact of such special clauses is more pervasive. In such cases the rhetoric of human rights law has evidently played a particular role in the constitution-making process, inducing constitution-makers to attribute a special force de resistance to a specific category of international treaties capable of guaranteeing fundamental values at the domestic level.

Another common solution adopted by some constitutions is the requirement for constitutional provisions dealing with human rights to be interpreted in accordance with international instruments, according to an approach originally included in article 10.2 of the 1978 Spanish Constitution. This solution has been highly influential and has been employed in several constitutions, such as article 18.3 of the 2006 Serbian Constitution according to which '[p]rovisions on human and minority rights shall be interpreted to the benefit of promoting values of a democratic society, pursuant to valid international standards in human and minority rights, as well as the practice of international institutions which supervise their implementation'. In this regard we could also mention constitutions of Angola (2010, article 26); Bolivia (2009, article 13); Cape Verde (1992, article 16); Colombia (1991, article 93); Ethiopia (1994, article 13); Moldova (1994, article 4); Mozambique (2004, article 43); Peru (1993, final provision); Romania (1991, article 20.1); and South Africa (1996, section 39). In these cases, human rights treaties and the case-law developed by international human rights monitoring bodies can play a significant complementary role in integrating constitutional provisions regarding fundamental rights and ensuring that their interpretation is in line with international legal standards.

In other cases constitutions simply proclaim the binding character of international human rights instruments at the domestic level. They may do so without necessarily providing human rights instruments with any special rank or, alter- 
natively, by stating that international instruments will complement the human rights provisions included in the constitution. This approach has, for instance, been used in the following constitutions: Angola (2010, article 26); Cambodia (1993, article 31); Cameroon (2008, preamble); Central African Republic (2004, preamble); Chile (1989, article 5); Côte d'Ivoire (2000, preamble); Guinea (2010, preamble); Niger (2010, preamble); and Rwanda (2003, preamble). The added value of such provisions could appear modest, as they mainly aim to pledge the fidelity of the domestic system to universal values. It might be contended that the international obligations provided by human rights treaties ought to be respected by domestic authorities once ratified and implemented even in the absence of specific constitutional clauses. Nonetheless the inherent scope of these constitutional provisions is to emphasise the richness of the catalogue of human rights provisions pertinent to the domestic legal order, thus highlighting the relevance of the human rights agenda for constitution-makers and the potential impact of international standards for the subsequent practice developed by domestic actors in this area. In yet other cases such provisions explicitly incorporate international soft-law documents at the domestic level, as in the case of article 5 of the 1993 Constitution of Andorra, which provides that ' $t$ the Universal Declaration of Human Rights is binding in Andorra', or article 7 of the 2004 Constitution of Afghanistan, claiming that ' $\mathrm{t}$ ] he state shall observe ... the Universal Declaration of Human Rights'. Additionally, human rights treaties are sometimes qualified as the ultimate yardstick of permissible limitations to constitutional rights, as potential derogations from constitutional human rights norms may not exceed the limitations provided by international treaties: this approach is seen, for instance, in article 17 of the 1998 Albanian Constitution or article 164 of the 2008 Ecuadorian Constitution. Finally, a constitutionally protected right to submit individual petitions to international organisations after the exhaustion of domestic remedies is provided for in article 46.3 of the 1993 Russian Constitution.

A survey of these provisions therefore emphasises the current importance attributed by contemporary constitutions to international human rights instruments. Such constitutions use international standards as an additional tool to protect basic values, also in order to provide the fundamental rights recognized by national texts with a 'safety net' supplied by external sources and actors. It is clear that processes of transition from former authoritarian regimes have facilitated the attribution of formal relevance to international human rights instruments by several contemporary constitutions. This is emphasised by the significant number of States involved in such political processes that have ultimately adopted one of the abovementioned approaches. In several cases it is clear that 
the insertion of such clauses represents a substantial concession to the pressing demands of the international community, especially with regard to constitutionmaking processes supported by external actors.

Furthermore, in numerous constitutions the concrete formal impact of human rights treaties on constitution-making processes and their potential relationship with constitutional texts is more indirect. In several cases international treaties have acted only as a source of inspiration during the process of drafting pertinent constitutional provisions, with no formal reference to them being included in the final text, such as in the 1996 South African Constitution. ${ }^{51}$ These solutions are nonetheless relevant as such rules, largely crafted on the basis of international instruments, ultimately obtain a constitutional rank, thus placing human rights standards at the highest level in the domestic legal order.

At the same time it is quite clear that such formal recognition may only represent a cosmetic solution for several States whose records of human rights violations are significant. Also in this case it is evident that constitutional provisions may only be one of several potential elements favouring the rule of law at the domestic level.

\subsection{Constitutional Provisions Clarifying Conditions for Ratified Treaties to Produce Legal Effects in the Domestic Legal Order}

The provisions analysed so far constitute only some of the potential constitutional clauses of relevance to the proper application of international treaties at the domestic level. In particular, the extent to which ratified international treaties might be considered part of the domestic legal system can depend upon conditions provided by the constitution which reflect the State's attitude towards international law.

Such provisions can also provide indications of the possible monist or dualist approach of the domestic legal system with regard to international law, even if it is well known that such an academic distinction mainly represents a legal archetype and is hardly capable of capturing the diverse nuances present in legal

${ }^{51}$ Dugard, International Law, above n 27, 84-6; T Maluwa, 'International Human Rights Norms and the South African Interim Constitution' (1994) 19 South African YIL 29; P Andrews, 'Incorporating International Human Rights Law in National Constitutions: the South African Experience' in R Miller \& R Bratspies (eds), Progress in International Law (2008) 35. 
orders. $^{52}$ Consequently these constitutional provisions reflect legal traditions concerning the role of treaties in domestic legal orders, such as clauses included in several Common law countries' constitutions requiring Parliaments to explicitly implement treaties into domestic law in order for them to have legal effect in the domestic legal system: a solution usually qualified as the quintessential example of a dualist approach to international law. Similarly, other constitutional provisions seek to clarify that treaties must be qualified as part of the domestic legal system and may be applicable once ratified and/or published in the official journal of the State in question, or once they have entered into force at the international level. Several contemporary texts make reference to at least some of the formulas discussed above, such as the Constitutions of: Albania (1998, article 122.1); Andorra (1993, article 3); Angola (2010, article 13.2); Armenia (1995, article 6); Bhutan (2008, article 10); Dominican Republic (2010, article 26); East Timor (2002, article 9); Ethiopia (1994, article 9); Kenya (2010, article 2); Kosovo (2008, article 19); Kyrgyz Republic (2010, article 6); Lithuania (1992, article 138); Macedonia (1991, article 118); Mongolia (1992, article 10); Mozambique (2004, article 18); Namibia (1990, article 144); Nigeria (1999, sect. 12.1); Paraguay (1992, article 141); Poland (1997, article 91); Qatar (2003, article 68); Serbia (2006, article 194); South Africa (1996, section 231); Swaziland (2005, article 238); Togo (1992, article 138); Ukraine (1996, article 9); and Zimbabwe (2013, article 34).

Taking into account the fact that several contemporary constitutions were adopted following periods in which international treaties were not even mentioned in the former constitutional texts, or were not properly accommodated for in the domestic legal system, it could be inferred that these general provisions can still play a potentially positive role. In particular such constitutional clauses may contribute to domestic legal certainty by emphasising some basic legal conditions necessary for international treaties to be qualified as part of the domestic legal order, thus practically guaranteeing their proper application at the domestic level by local actors.

At the same time, these provisions can hardly solve per se the most debated issues with regard to the relationship between treaties and other domestic sources, such as the possibility of attributing priority to international sources in cases of subsequent incompatible domestic acts. For instance, article 37 of the 2002 Bahrain Constitution simply affirms that 'a treaty shall have the force of

\footnotetext{
${ }^{52}$ E Cannizzaro and B Bonafè, 'Beyond the Archetypes of Modern Legal Thought' in M Maduro, K Tuori \& S Sankari (eds), Transnational Law: Rethinking European Law and Legal Thinking (2014), 78.
} 
law once it has been concluded and ratified and published in the Official Gazette' In such cases of an absence of clear indications provided by the constitution, the concrete practice developed by domestic actors will take on a pivotal role in resolving potential conflicts with domestic sources.

Finally, it is well known that additional practical problems can arise concerning the application of treaties at the domestic level, such as with regard to treaties including non self-executing provisions. This issue can hardly be resolved by constitutions in general terms, but in some cases the problem has been expressly recognised by contemporary constitutional provisions. For instance, some constitutions provide that treaties are inapplicable to the extent that their provisions are not self-executing, as in article 19 of the 2008 Constitution of Kosovo and other texts. ${ }^{53}$ Yet other constitutions provide that self-executing treaties may be directly applied without the need to pass a national act: this is the case, for instance, of the 1996 South African Constitution. ${ }^{54}$ These provisions consequently take on a mainly didactic role for national legal actors. Their main purpose appears to be to emphasise the potential interpretative difficulties regarding the application of international treaties in domestic legal systems, taking into account the relevant experiences of other States. ${ }^{55}$ Evidently such constitutional provisions cannot have any direct impact in facilitating the subsequent identification by domestic actors of provisions qualified as non-self-executing. Nonetheless they constitute further signs of the potential level of accuracy that some contemporary constitutions possess with respect to the problems posed by the relationship between international and domestic legal orders.

\footnotetext{
${ }^{53}$ This provision was strongly influenced by the similar article 122.1 of the 1998 Albanian Constitution. See also article 91 of the 1997 Polish Constitution: 'After promulgation thereof in the Journal of Laws of the Republic of Poland, a ratified international agreement shall constitute part of the domestic legal order and shall be applied directly, unless its application depends on the enactment of a statute'.

${ }^{54}$ South African Constitution (1996), s 231.4: 'Any international agreement becomes law in the Republic when it is enacted into law by national legislation: but a self-executing provision of an agreement that has been approved by Parliament is law in the Republic unless it is inconsistent with the Constitution or an Act of Parliament'. For the difficulties posed by this latter provision, see Dugard, International Law, above n 27, 83.

${ }^{55} \mathrm{~T}$ Buergenthal, 'Self-Executing and non Self-Executing Treaties in National and International Law' (1992) 235 RCADI 303.
} 


\section{Customary International Law and Contemporary Constitutions}

Customs and general principles of international law are fundamental sources of international law, as evidenced by article 38 of the Statute of the International Court of Justice. Nonetheless early examples of constitutional texts had the tendency to neither mention them as potentially relevant sources for the domestic legal order nor attribute them a special rank, due to the series of legal and political reasons emphasised above. ${ }^{56}$ Contemporary constitutions tend to partly go beyond this approach. Even if it is correct to maintain that a significant number of constitutions still ignore these international sources, ${ }^{57}$ nowadays a series of constitutional provisions aim to accommodate such rules within the domestic legal order by modifying positions maintained in previous texts. ${ }^{58}$

In some cases customary international law and general principles of international law have been formally granted a higher status than acts of Parliament. In these, such sources are given a significant force de resistance with respect to any potentially conflicting normative solutions provided by the legislature. In this regard, mention could be made of article 8 of the 1991 Slovenian Constitution, which proclaims that '[1]aws and regulations must comply with generally accepted principles of international law'. This position is substantially shared by other constitutions such as: Belarus (1996, article 8); Montenegro (2007, article 9) and Serbia (2006, article 16). In other cases the constitution limits itself to proclaiming that international customary law and, eventually, general principles of international law are accepted as part of the domestic legal system, as maintained by article 9 of the 2002 Constitution of East Timor, which affirms that '[1]he legal system of East Timor shall adopt the general or common principles of international law'. This solution is also adopted, for instance, by the constitutions of: Angola (2010, article 13); Bosnia-Herzegovina (1995, article 3); Cape Verde (1992, article11); Dominican Republic (2010, article 26); Estonia (1992, article 3); Georgia (1995, article 6); Hungary (2011, article Q); Kyrgyzstan (2010, article 6); Mongo-

\footnotetext{
${ }^{56}$ For an examination of the neglect of customs by early constitutions see Cassese, 'Modern Constitutions,' above n 2, 368-93.

${ }^{57}$ For an empirical political science analysis, see T Ginsburg, A Chernykh \& Z Elkins, 'Commitment and Diffusion: How and Why National Constitutions Incorporate International Law' (2008) $U$ Ill LR 201, 223-6, 233.

${ }^{58}$ It should be emphasized that, while the broad wording of relevant constitutional provisions could accommodate in the domestic legal system both customs and general principles of international law, in this paragraph mention is mainly made to customary international law due to the scarce reference to general principles of international law in state practice.
} 
lia (1992, article 10); Mozambique (2004, article 18); Namibia (1990, article 144); Russia (1993, article 13); Serbia (2006, article 16); Slovakia (1992, article 1); and Turkmenistan (2008, article 6).

The relevance of the latter provisions should not be underestimated. This kind of constitution clearly favours the direct and automatic application of customary provisions within the domestic legal order, providing for their automatic standing incorporation and implying, for instance, that the enactment of a domestic act would not be necessary for their application. As emphasized by scholars, such a choice regarding national constitutions is almost obligatory due to the nature of such international rules, which emerge gradually in the international sphere and whose application at the domestic level can hardly be limited by the enactment of a specific statute by Parliament with the aim of adopting the content of customary international provisions. ${ }^{59}$

Furthermore, subsequent domestic practice could also infer key additional consequences through similar provisions. One example is the possibility to deduce from such clauses the attribution of a constitutional or infra-constitutional rank to customary international law, thus permitting courts to allow conflicting acts of Parliament to be subordinated to custom, as maintained in the case-law of several States. ${ }^{60}$ In some cases this supremacy has been clearly expressed by constitutional provisions attributing to superior courts the duty to rule 'on the compatibility of domestic laws with the universally recognised norms of international law', as maintained by article 149 of the 1991 Bulgarian Constitution or articles 167 and 194 of the Serbian Constitution.

Similarly, customary international law is also qualified as part of the domestic legal system by constitutions adopting the common law approach: article 2.5 of the 2010 Constitution of Kenya, for example, maintains that ' $t$ ] he general rules of international law shall form part of the law of Kenya'. This has been affirmed in similar terms in the constitutions of Malawi (1994, article 211) South Africa (1996, section 232) and Zimbabwe (2013, article 326), which also reiterate the basic legal assumption of common law systems, aiming to admit the application of customary international law unless 'inconsistent with the Constitution or an Act of Parliament'. Consequently in such cases constitutions and acts of Parliament laws would prevail in the case of conflicts with customary rules. This position

\footnotetext{
${ }^{59}$ Cassese, International Law, above n 31, 224.

${ }^{60}$ See e.g. the position maintained by the Italian Constitutional Court with regard to article 10 of its Constitution proclaiming that customary laws are part of the domestic legal system: G Cataldi, 'Italy', in D Shelton, above n 34, 343-346.
} 
is clearly influenced by the case-law developed by English courts in this regard, which flows from the doctrine of parliamentary sovereignty ${ }^{61}$.

Furthermore it should be emphasised that, in several cases, broad constitutional provisions referring to the role of international law have subsequently been interpreted by relevant national actors as being able to accommodate international customs within the domestic legal system. For instance, mention could be made of article 9 of the 1997 Constitution of Poland, which generally proclaims that ' $[t]$ he Republic of Poland shall respect international law binding upon it'. Even if an express reference to customary law is not provided, this rule has constantly been interpreted by Polish courts as confirming the automatic application of general international law within the domestic legal system. ${ }^{62}$ Attention should therefore be paid to other constitutional provisions pledging fidelity to international law, as in the case of article 8 of the 1995 Constitution of Kazakhstan, which proclaims that ' $\mathrm{t}$ ]he Republic of Kazakhstan shall respect principles and norms of international law', adopting a solution maintained by other States as for instance Lithuania (1992, article 135), Ukraine (1996, article 18), and Uzbekistan (1992, preamble and article 17).

In these cases the potential reverse impact on the domestic legal level of these constitutional provisions, aimed at emphasising a declaratory commitment to international law, should be evaluated within each legal system according to relevant practice. This assessment would need to consider the possible auxiliary role that national courts could attribute to such express references to international law in their constitutions, in order to refer to customary law in disputes submitted to their attention when express reference to general international law is lacking from their constitutions.

Consequently, a comprehensive evaluation of contemporary constitutions clearly emphasises permanent difficulties in providing customary international law with an explicit role in domestic legal systems. Once previous 'political' oppositions to general international law had been abandoned by significant groups of States, customary law could have been expected to become a recurrent element in the legal analysis of international law issues within the framework of constitution-making processes, taking into account its constant relevance in international law and in disputes submitted to domestic courts. However this has not been the case. It is probable that general international law is still perceived as an international legal source that is difficult for the individual

\footnotetext{
${ }^{61} \mathrm{~J}$ Crawford, Brownlie's Principles of Public International Law (8 ${ }^{\text {th }}$ ed, 2012), 69-70.

${ }^{62}$ See e.g. A Wyrozumska, 'Poland', in D Shelton, above n 34, 486.
} 
States concerned to manage. Therefore, States may be reluctant to formally proclaim its inclusion within domestic legal sources, even if this attitude can hardly preclude its potential relevance at the domestic level. Furthermore, the previous poor record of references to customary international law in early constitutions may also have had an indirect but significant negative impact in this area. Indeed, the phenomenon of cross-fertilisation among the texts of different States, as well as references by constitution-makers to previous versions of their own constitutions omitting the role of customary law, can contribute to the persistence of constitutions that neglect to provide specific recognition for general international law. Finally, for States adopting a common law approach, the absence of express references to customary international law in their constitutions can mainly be interpreted on the basis of the existence of consolidated judicial practice. The latter confirms the doctrine of incorporation, thus maintaining that customs are automatically part of the law of the land even if it should be emphasised that according to this position constitutional provisions and acts of Parliament laws tend to prevail in the case of conflicts with customary rules. ${ }^{63}$ Consequently, an express mention of customary law in constitutions could be qualified as unnecessary for the benefit of the domestic legal order.

At the same time, taking into account the previous scenario, the current tendency confirms a partial shift in this area, as the number of States making reference to customary law in their constitutions is certainly higher than prior to the 1990s. This trend could consequently be interpreted as an additional confirmation of the corresponding increase in openness towards international law amongst contemporary constitutions. Furthermore, notwithstanding the apparent indifference of many constitutions with regard to general international law, this attitude can hardly prevent domestic legal systems from taking such rules into account in subsequent domestic practice. Even if general international law has been partly superseded by the adoption of key agreements in areas previously regulated exclusively by customary law, significant issues remain dominated primarily by this latter source, as the law of immunities. Consequently, national legal actors will in any case have to face problems raised by the application of these international rules without the help of clear indications in their constitutions, thus further emphasizing their subsidiary and creative role in the presence of

${ }^{63}$ Crawford, above n 61, 67-71. For further examples of the possibility of applying customary international law even in the absence of express references provided by the Constitution, on the basis of the doctrine of incorporation, see e.g.: B Akinrinade, 'Nigeria,' in D Shelton, above $\mathrm{n}$ 34, 461-2; H Onoria, 'Uganda,' in D Shelton, above n 32, 609. 
vague or incomplete constitutional provisions. ${ }^{64}$

\section{Binding Acts of International Organisations}

A final mention must be made of constitutional provisions dealing with unilateral acts of international organisations. As it is well-known, few international organisations can impose their binding acts on Member States: this hypothesis mainly refers to resolutions adopted by the Security Council or acts pertaining to regional organisations, such as the European Union or, similarly, the East African Community. In these cases, the pervasiveness of the law-making powers exercised by some of these international organisations can have a significant impact on the domestic legal order and constitution-making processes should consequently pay increasing attention to such hypotheses.

However, even if scholars have rightly maintained that ' $\mathrm{f}$ ] security, it would be advisable for national constitutions to make express provision for the incorporation of binding decisions of international organizations, ${ }^{65}$ only in a few cases have contemporary constitutions made express reference to the binding acts of international organisations in order to properly accommodate these sources within their domestic legal orders. In this regard, an early example could be found in article 11 of the 1992 Constitution of Cape Verde which affirms that '[j] udicial acts emanating from competent offices of supranational organizations to which Cape Verde belongs shall take effect in internal law as soon as they have been established in respective legal conventions'. Similarly we can mention article 122 of the 1998 Albanian Constitution. This provides that ' $\mathrm{t}]$ he norms issued by international organizations have priority, in case of conflict, over the law of the country when the direct application of these norms issued by the organization is expressly contemplated in the agreement ratified by the Republic of Albania for participation therein'. This solution is also adopted by article 20 of the 2008 Constitution of Kosovo. Furthermore, the regional integration provided for by the EU has also required a series of European States to modify their constitutions, dealing with this phenomenon through a series of specific provisions. This is exemplified, for instance, by the latest constitutional provision adopted in this area, namely Article E of the 2011 Hungarian Constitution, which proclaims " $t$ ] he

\footnotetext{
${ }^{64} \mathrm{~J}$ Combacau \& S Sur, Droit international public $\left(10^{\text {th }}\right.$ ed, 2012), 187.

${ }^{65} \mathrm{~J}$ Polakiewicz, 'International Law and Domestic (Municipal) Law, Law and Decisions of International Organizations and Courts' (2011) Max Planck Encyclopedia of Public International Law (on-line edition), para 5.
} 
law of the European Union may stipulate binding rules of conduct'. However, the specific constitutional issues raised by the EU integration process is beyond the scope of this article. ${ }^{66}$

Accordingly, it is evident that, in the majority of cases, the importance of the phenomenon of integration and cooperation among States within the framework of international organisations and its impact on national legal systems through their binding unilateral acts has been accommodated by national constitutions through a series of generic provisions. These clauses strive to accommodate the influence of supranational organisations, on the one hand, with domestic sovereignty issues on the other, as provided in similar terms by article 172 of the 2010 Nigerian Constitution and article 96 of the 2001 Constitution of Senegal, which admit the possibility of entering into agreements involving the 'partial or total abandonment of sovereignty' in order to achieve international cooperation.

As it is known, such generic provisions allowing the State to accede to international organisations and limiting their sovereign powers have been interpreted as a sufficient legal basis for the participation of States concerned in international organizations and, eventually, provide a constitutional basis for the subsequent applicability of such sources. Nonetheless, taking into account the increasing pervasiveness of such unilateral acts, which can also directly affect the legal position of individuals, current constitution-making processes could have been expected to pay appropriate attention to this phenomenon, by including clear constitutional provisions in this regard. A specific mention of these international sources would have been particularly useful to clarify basic issues, such as their legal position with regard to municipal sources and the conditions necessary for their direct application within the domestic legal system, especially in the light of the diverging solutions reached so far by the case-law of domestic authorities. Consequently the inclusion of specific constitutional provisions devoted to international organizations and their unilateral acts appears to be a fundamental element for evaluation in contemporary constitution-making processes and their absence, considering the relevance of international organisations, can hardly be justified by the novelty of the phenomenon, as maintained by some authors. ${ }^{67}$

\footnotetext{
${ }^{66}$ For further references, see European Commission for Democracy through Law, European Integration and Constitutional Law (2001). Moreover, see the European national case-studies analysed in D Shelton, above $\mathrm{n} 34$.

${ }^{67}$ See D Carreau \& F Marrella, Droit international (11 ${ }^{\text {th }}$ ed, 2012), 536.
} 


\section{Conclusion}

The analysis provided so far has confirmed that the increased interrelationship between the international and domestic legal orders has become so pervasive that contemporary constitutions can hardly ignore this issue. The significant trend of contemporary constitution-making processes to facilitate the openness of domestic legal systems towards international law cannot be underestimated. As examined above, different mechanisms have been developed in this regard, clearly aiming to favour the subsequent proper application of international sources by domestic actors. A particular mention should be made of the formal primacy accorded by several constitutions to international rules over municipal law (especially with regard to treaties and, in significant cases, also to customs); of the extensive role played by international human rights standards in supporting references to fundamental rights in national constitutions; and of provisions clarifying requirements for international rules to be part of the domestic legal system.

Some common 'ideological' factors can easily be identified as favouring this approach. For example, States that have experienced authoritarian regimes have shown a greater willingness to expressly incorporate international law sources in their constitutions so as to provide domestic legal orders with an external 'safety net'. ${ }^{6}$ Furthermore, the constant cross-fertilisation amongst constitutions and their increasing convergence may certainly play a positive role in this regard. It is evident that the ever greater number of texts providing appropriate references to international sources increases the likelihood of these constitutional clauses being replicated in other contexts. In general terms, taking into account the previous scenario regarding constitutions adopted prior to the 1990s, the current tendency confirms a significant shift in this area towards the 'internationalization' of contemporary constitutions.

Nonetheless, constitution-making processes are far from having developed a comprehensive approach, embracing all potential legal difficulties that characterise relations between international and municipal sources. The inconstant attitude of constitution-makers with regard to international law is visible in several constitutions, as even within the same text one can find specific attention being dedicated to some issues, while others deserving of proper analysis are neglected.

\footnotetext{
${ }^{68}$ See A Cassese, 'Modern Constitutions,' above n 2; E Stein, 'International Law in Internal Law: Toward Internationalization of Central-Eastern European Constitutions?' (1994) 88 AJIL 427, 447; D Shelton, 'Introduction', in D Shelton, above n 34, 2.
} 
It seems evident that it is still hard to guarantee a proper and comprehensive role for international law issues during constitution-making processes.

This limit may be the product of different reasonings. First, difficulties in appreciating the complex technical ramifications of the relationship between international and domestic legal orders should not be underestimated, especially with reference to States with a poor record of reference to international law aspects in previous constitutional texts and national judicial practice. ${ }^{69}$ Similarly, other key legal issues pertaining to the domestic dimension of a constitution, such as the separation of powers or the relationship between central and local authorities, usually acquire a pivotal role in the drafting process, to the detriment of other topics such as the international law dimension of the future text, which are qualified as less relevant legal technicalities. ${ }^{70}$ Furthermore - an element that will be emphasized later on - sovereignty concerns with regard to the potentially intrusive role played by international law probably play a catalytic role in constitution-makers' determination to adopt a reserved stance vis-à-vis international law.

Consequently international law issues have not been part of the main agenda of several contemporary constitution-making processes, despite some of them being driven or supported by external actors. In fact a similar trend can be recognized in the case of internationalised pouvoir constituent, where a significant role has been played by international actors through the provision of external technical expertise. A survey of constitutions adopted in these latter scenarios has emphasised that the relationship between international and domestic sources has not been properly analysed in various cases. This element confirms that international law issues could be underestimated for the benefit of other areas qualified as more relevant as they are the subject of possible political pressure exercised by international actors, such as constitutional provisions guaranteeing the rule of law and fundamental rights. ${ }^{71}$

Furthermore, some solutions adopted in contemporary constitutions are also far from being satisfactory from an international law perspective. For instance several contemporary constitutions still formally ignore customary law,

\footnotetext{
${ }^{69}$ See e.g. A J Bělohlávek, 'The Czech Republic,' in D Shelton, above n 34, 206: 'After the fall of the Iron Curtain, the political leaders drafted the Constitutions with minimal experience in international law, which led them to include some serious systemic flaws'.

${ }^{70}$ See E Stein, 'International Law,' above n 22, 447.

${ }^{71}$ See e.g. M Schoiswohl, 'Linking the International Legal Framework to Building the Formal Foundations of a "State at Risk": Constitution-Making and International Law in Post-Conflict Afghanistan' (2006) 39 Vand J Trans L 819.
} 
although it should be mentioned that, in comparison to previous texts, a greater number of States now include references to general international law in their constitutions. A similar concern could be expressed with regard to the binding acts of international organizations.

These international law sources usually fall into a legal black hole in contemporary constitutions as they are substantially ignored in constitution-making processes, as also emphasized with reference to domestic clauses claiming the supremacy of constitutions over international law sources. As analysed above, the trend in contemporary constitutions is mainly to explicitly limit both claims of supremacy and the creation of mechanisms to pre-review the compatibility of values expressed in the constitution with treaties - namely, a source of international law that is easily managed by the State itself. These clauses of supremacy regarding treaties are, in our opinion, far from being irreconcilable with international law. In the case of conflict between treaties and constitutional provisions their final effect is limited to an impasse in the State's participation in the proposed treaty, unless such primacy is claimed after the ratification process, leading to obvious problems of State responsibility in the case of subsequent nonfulfillment of international obligations.

On the contrary the most significant problems may arise with regard to the usually unsettled issue of the relationship between customs and binding unilateral acts of international organisations on the one hand and the constitution and other domestic sources on the other. Constitution-makers prefer to avoid dealing with situations of potentially competing interests by deferring the resolution of eventual conflicts to subsequent domestic practice. Nonetheless this short-sighted attitude, which emphasises the difficulties of managing sources of international law whose efficacy and binding character are far from being subject to the individual will of a State, cannot really help avoid subsequent problems: this is seen in the now classic examples of potential conflicts between the human rights values promoted by constitutions and customs or mandatory unilateral acts of international organisations. As we know, such difficulties in reconciling diverging interests between constitutional values and international commitments have given rise to intense debate.

On the one hand these possible clashes seem more the product of the concomitant competing international values at stake, which benefit from the possibility of recurring to domestic mechanisms of control in attempts to solve the issues, rather than the result of an inconceivable relationship between international and domestic legal values. Consequently claims for the supremacy of constitutional values could also have a beneficial impact on international law itself, 
which favours the reconsideration of existing norms and procedures that have suffered from intrinsic deficiencies, as was once put to the test by domestic control mechanisms. In this regard, it is sufficient to mention developments within the European Union (EU) system concerning human rights and modifications introduced to the UN's sanction regimes. Unsurprisingly, even an increasing number of international law scholars tend to evaluate the possibility of attributing a potentially priority role to constitutional values positively, as they see them as valuable 'emergency brakes' in the case of international rules that disregard basic fundamental rights, result from international law-making processes qualified as democratically deficient, ${ }^{72}$ or, alternatively, admit the protection of core constitutional values as a circumstance precluding wrongfulness. ${ }^{73}$ Some of these proposals therefore tend to introduce key elements of legitimacy and rule of law to the international law agenda, favouring the so-called constitutionalisation of international law, i.e. 'an attempt to exercise legal control over politics within the international legal order itself, in order to compensate for the erosion of such control within domestic constitutional orders. ${ }^{74}$

On the other hand, the difficulties of accepting solutions that favour the primacy of constitutional values over international sources are nonetheless obvious. The potential risks are twofold: (1) jeopardising the basic principle of the supremacy of international law thus represents a risk for the maintenance of its normative role and its effectiveness; and (2) fragmenting international law, chiefly because of the difficulties in identifying core constitutional principles and domestic legal orders that are entitled to demand such a constitutional right to resistance, sometimes exclusively attributed to 'liberal democracies. ${ }^{75}$ In this

${ }^{72}$ See e.g.: T Cottier, D Wüger, 'Auswirkungen der Globalisierung auf das Verfassungsrecht: Eine Diskussionsgrundlage,' in B Sitter-Liver (ed), Herausgeforderte Verfassung: Die Schweiz im globalen Konzert (1999) 241, 263-4; A Peters, Supremacy Lost: International Law Meets Domestic Constitutional Law, Vienna Journal of International Constitutional Law, vol 3, (2009) 195-6. See also A Noalkamper, 'The Rapprochement between the Supremacy of International Law at International and National Levels,' in R Wolfrum (ed), Select Proceedings of the European Society of International Law (2010) 239.

${ }^{73}$ B Conforti, Diritto internazionale (2011) 258.

${ }^{74}$ De Wet, above n 7, 1213. See also B Fassbender, 'The Meaning of International Constitutional Law,' in N Tsagourias (ed), Transnational Constitutionalism: International and European Models (2007) 307, 308; W G Werner, 'The Never-ending Closure: Constitutionalism and International Law, ibid, 329, 330.

${ }^{75}$ A von Bogdandy, 'Pluralism, Direct Effect, and the Ultimate Say: On the Relationship between International and Domestic Constitutional Law' (2008) 6 Int J Const L 397, 398: 'given the state of development of international law, there should be the possibility, at least in liberal democracies, of placing legal limits on the effect of a norm or an act under international law within the domestic legal order if it severely conflicts with constitutional principles'. 
latter case the risk of arbitrarily differentiating among States is evident, as only some domestic legal orders would still be obliged to guarantee a blanket priority to international law as they could be identified as pariahs of the international legal community, while other more privileged States could adopt an à la carte approach towards international obligations. Furthermore, it is well known that the protection of constitutional values was not qualified as a proper circumstance precluding wrongfulness by the ILC in the Draft Articles on Responsibility of States, thus reducing the possibility of admitting such a solution.

In conclusion, even if the difficulties of properly accommodating international law sources in national constitutions are still present, it is possible to recognize a substantial trend towards the 'internationalisation' of contemporary constitutions as the most recent texts appear significantly receptive to international law standards and sources. In this regard the cross-fertilization among constitutions plays a relevant role, which is accentuated by states having regional affiliations or sharing similar legal traditions. This conclusion is, however, inherently limited by the characteristics of the current analysis, which has been limited to a formal examination of constitutional provisions in this area. It is clear that such an evaluation should be supplemented by an analysis of the effective attitudes of States towards international rules within their own domestic legal orders. In fact the practice developed by domestic actors (mainly national judges) plays a fundamental role in addressing and resolving legal problems within international and domestic sources and in providing concrete content to constitutional provisions dealing with international law. Nonetheless, the activities of domestic actors and their ability to favour or impede the proper application of international sources at the domestic level is highly dependent upon the formal solutions provided by constitutional provisions. Consequently, this element confirms the crucial role potentially played by constitution-making processes in favouring the effectiveness of international law, as the desirable supremacy of international law over national sources can certainly be facilitated by 'friendly' approaches to international law on the part of domestic constitutions. 